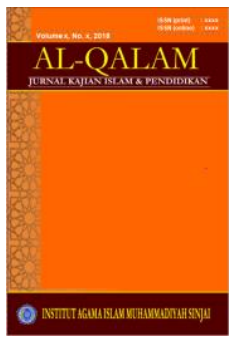

AL-QALAM

Jurmal Kajian Islam \& Pendidikan

Volume 9, No. 1, 2017

ISSN (print) : 1858-4152

ISSN (online) : :xxx-xxxx

Homepage : http://journal.iaimsinjai.ac.id/index.php/al-qalam

\title{
PERAN GURU DAN KEPALA SEKOLAH DALAM PENGEMBANGAN KURIKULUM MADRASAH DI MTS MUHAMMADIYAH BALANGNIPA
}

\author{
Oleh: Nurhasanah ${ }^{1}$
}

$* * *$

\begin{abstract}
Abstrak
Kurikulum memegang peranan penting dalam pendidikan, sebab berkaitan dengan penentuan arah, isi dan proses pendidikan yang pada akhirnya menentukan macam dan kualifikasi lulusan suatu lembaga pendidikan. Seiring dengan perkembangan jaman dan tuntutan dari masyarakat, maka dunia pendidikan harus melakukan inovasi dalam pendidikan. Inovasi pendidikan akan berjalan dan mencapai sasarannya jika program pendidikan tersebut dirancang dan di implementasikan sesuai dengan kondisi dan tuntutan jaman. Adapun metode penelitian yang digunakan dalam penelitian ini adalah metode kualitatif dengan pendekatan deskriptif dan observasi lapangan juga penelaahan terhadap buku-buku yang relevan. Peran Guru dan Kepala Sekolah dalam Pengembangan Kurikulum adalah Sebagai implementer, guru berperan untuk mengaplikasikan kurikulum yang sudah ada dan kepala sekolah sebagai pengontrol. Dalam pengembangan kurikulum guru dianggap sebagai tenaga teknis yang hanya bertanggung jawab dalam mengimplementasikan berbagai ketentuan yang $a d a$.
\end{abstract}

Kata Kunci : Guru dan Kepala Sekolah, Pengembangan, Kurikulum

\section{PENDAHULUAN}

ebagai implikasi dari pentingnya inovasi pendidikan menuntut kesadaran tentang peranan Kepala sekolah dan guru. Sebagai tenaga professional, kepala sekolah guru merupakan pintu gerbang inovasi sekaligus gerbang menuju pembangunan yang terintegrasi. Hal ini dikarenakan pembangunan dapat terlaksana jika dimulai dari membangun manusianya terlebih dahulu. Tanpa manusia yang cakap, terampil, berpengetahuan, cerdas, kreatif dan bertanggung

${ }^{1}$ Dosen Tetap Pada Institut Agama Islam Muhammadiyah Sinjai 


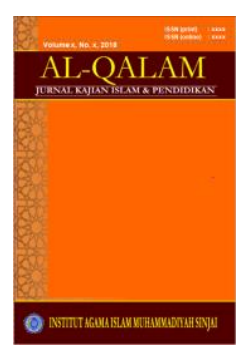

AL-QALAM

Jurnal Kajian Islam \& Pendidikan

Volume 9, No. 1, 2017

ISSN (print) : : 1858-4152

ISSN (online) : xxxx-xxxx

Homepage : http://journal.iaimsinjai.ac.id/index.php/al-qalam

jawab maka pembangunan yang terintegrasi tidak akan dapat terlaksana dengan baik. Oleh karena itu, setiap guru dan tenaga kependidikan lain harus memahami kurikulum dengan sebaik- baiknya.

Ilmu pengetahuan dan teknologi selalu berkembang dan mengalami kemajuan sesuai dengan perkembangan zaman dan perkembangan cara berpikir manusia. Kemajuan ilmu pengetahuan dan teknologi tersebut juga menyebabkan terjadinya perkembangan dalam kehidupan masyarakat. Perkembangan itu pula menyebabkan perubahan pandangan terhadap tujuan pendidikan sehingga diperlukan adanya perubahan dan penyesuaian kurikulum.

Pengembangan kurikulum dilaksanakan sebagai langkah antisipasi dalam menjawab tantangan yang muncul akibat perkembangan - perkembangan tersebut dengan tetap memperhatikan situasi dan kondisi serta norma-norma yang berlaku di masyarakat. Langkah pengembangan kurikulum diatur sedemikian rupa sesuai dengan hakekatnya agar peserta didik sebagai komponen pembelajaran mendapat kompetensi yang memadai dalam menguasai dan memanfaatkan teknologi sesuai dengan yang diinginkan.

Guru memiliki andil yang sangat besar terhadap keberhasilan pembelajaran di sekolah. Guru sangat berperan dalam membantu perkembangan peserta didik untuk mewujudkan tujuan hidupnya secara optimal. Di dalam kelas guru malaksanakan dua kegiatan pokok yaitu kegiatan mengajar dan kegiatan mengelola kelas.Di kelas juga segala aspek pendidikan pengajaran bertemu dan berproses. Guru dengan segala kemampuannya, siswa dengan segala latar belakang dan sifatsifat individualnya, kurikulum dengan segala komponennya, dan materi serta sumber pelajaran dengan segala pokok bahasanya bertemu dan berpadu dan berinteraksi di kelas. Guru harus memiliki, memahami dan terampil dalam menggunakan macam-macam pendekatan dalam manajemen kelas, meskipun tidak semua pendekatan yang dipahami dan dimilikinya dipergunakan bersamaan atau sekaligus. Dalam hal ini, guru dituntut untuk terampil memilih atau bahkan 


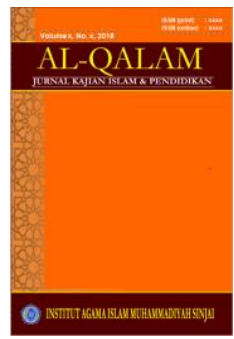

AL-QALAM

Jurnal Kajian Islam \& Pendidikan

Volume 9, No. 1, 2017

ISSN (print) : 1858-4152

ISSN (online) : :xxx-xxxx

Homepage : http://journal.iaimsinjai.ac.id/index.php/al-qalam

memadukan pendekatan yang menyakinkan untuk menangani kasus manajemen kelas yang tepat dengan masalah yang dihadapi.

\section{RUMUSAN MASALAH}

Berangkat dari paparan singkat fenomena di atas, maka permaslahan yang diangkat dalam penelitian ini sebagai sebagai rumusan ialah:

a. Apa Pengertian Kurikulum?

b. Bagaiamana peran guru dan Kepala Sekolah dalam pengembangan kurikulum?

\section{METODE PENELITIAN}

\section{A. Pedekatan dan Jenis Penelitian}

Adapun metode penelitian yang digunakan dalam penelitian ini adalah metode kualitatif dengan pendekatan deskriptif dan observasi lapangan juga penelaahan terhadap buku-buku yang relevan. Penelitian kualitatif adalah penelitian yang bermaksud untuk memahami fenomena tentang apa yang dialami oleh subjek penelitian misalnya perilaku, persepsi, motivasi, tindakan dan lain-lain secara holistik, dan dengan cara deskripsi dalam bentuk kata-kata dan bahasa, pada suatu konteks khusus yang alamiah dan dengan memanfaatkan berbagai metode alamiah. ${ }^{2}$

Masalah dalam penelitian ini adalah konsep guru tentang pembelajaran kejujuran dalam konteks pendidikan karakter untuk mencegah perilaku koruptif. Hal untuk meneliti bagaimana konsep guru mengenai pembelajaran kejujuran untuk mencegah perilaku koruptif maka digunakanlah pendekatan kualitatif.

Whithney dalam Soejono dan H. Abdurrahman mengatakan bahwa metode deskriptif ialah pencarian fakta dengan interpretasi yang tepat. Selanjutnya. Moh Nazir juga mengatakan bahwa penelitian deskriptif mempelajari maslah-masalah dalam masyarakat, serta tata cara yang berlaku dalam masyarakat serta situasi-

\footnotetext{
${ }^{2}$ Lexy J. Moleong, Metode Penelitian Kualitatif, (Bandung: Remaja Rosdakarya, 2007), h. 6.
} 


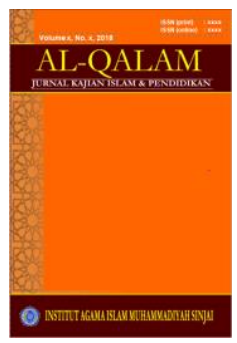

AL-QALAM

Jurnal Kajian Islam \& Pendidikan

Volume 9, No. 1, 2017

ISSN (print) : 1858-4152

ISSN (online) : xxxx-xxxx

Homepage : http://journal.iaimsinjai.ac.id/index.php/al-qalam

situasi tertentu, termasuk tentang hubungan kegiatan-kegiatan, sikap-sikap, padangan-pandangan, serta proses-proses yang sedang berlangsung dan pengaruh dari satu fenomena. ${ }^{3}$

Sedangkan ciri-ciri penelitian deskriptif menurut Hadari Nawawi dalam Soejono dan H. Abdurrahman ialah:

a. Memusatkan perhatian pada masalah-masalah yang ada pada saat penelitian dilakukan atau maslah-masalah yang bersifat aktual

b. Menggmbarkan fakta-fakta tentang masalah yang diselidiki sebagaimana adanya di iringi ditengah interpretasi rasional. ${ }^{4}$

Pada umumnya, dalam penelitian dikenal dua jenis penelitian yakni, penelitian kuantitatif dan kualitatif. Dalam bukunya Sugiyono mengartikan penelitian kuanitiatif sebagai metode penelitian yang berlandaskan pada filasafat positivisme, digunakan untuk meneliti pada populasi atau sampel tertentu, teknik pengambilan sampel pada umumnya dilakukan secara random, pengumpulan data, penggunaan istrumen penelitian, analisis data bersifat kuantitatif/statistik dengan tujuan untuk mengkaji hipotesis yang telah ditetapkan.$^{\mathbf{5}}$

Sedangkan penelitian kualitatif menurut beliau adalah penelitian yang berlandaskan pada filsafat post positivisme, digunakan untuk meneliti pada kondisi objek yang alamiah, dimana peneliti adalah sebagai instrumen kunci, pengambilan sampel sumber data dilakukan secara Purposive dan snowball, teknik pengumpulan dengan tringulasi (gabungan), analisis data bersifat induktif/kualitatif dan hasil penelitian kualitatif lebih menekankan makna dari pada generalisasi.

Ditinjau dari pelaksanaannya, penelitian ini termasuk jenis penelitian non eksprimental (dilakukan tanpa eksperimen). Dilihat dari datanya, penelitian ini termasuk deskriptif karena meneliti status gejala menurut apa adanya pada

\footnotetext{
${ }^{3}$ Soejono dan H. Abdurrahman, Metode Penelitian:Suatu Pemikiran dan Penerapan, (Jakarta: PT Rineka Cipta, 1999), h. 21.

${ }^{4}$ Soejono dan H. Abdurrahman, Metode Penelitian:Suatu Pemikiran dan Penerapan, h. 23.

${ }^{5}$ Sugiyono, Metode Penelitian Pendidikan, Pendekatan Kuantitatif, dan R\&D(Cet, XI; Bandung: Alfabeta, 2010), cet ke empat, h. 14-15
} 


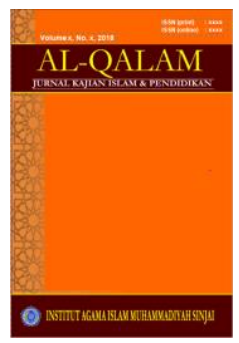

AL-QALAM

Jurnal Kajian Islam \& Pendidikan

Volume 9, No. 1, 2017

ISSN (print) : 1858-4152

ISSN (online) : xxxx-xxxx

Homepage : http://journal.iaimsinjai.ac.id/index.php/al-qalam

saatpenelitian dilakukan. ${ }^{6}$ Landasan teoritis dari penelitian kualitatif itu bertumpu secara mendasar pada fenomenologi. Fenomeologis adalah mencari arti dari pengalaman hidup berkenaan dengan konsep, pendapat, pendirian, sikap, penilaian, dan pemberian makna terhadap situasi. ${ }^{7}$

Olehnya dengan memperhatikan kedua pengertian diatas, dengan jelas menunjukkan bahwa penelitian yang dilakukan oleh peneliti tergolong penelitian kualitatif, dalam bukunya Lexy J Moleong mengemukakan beberapa pendapat dari para ahli diantaranya dari Bogdan dan Taylor yang mendefinisikan metodologi kualitatif sebagai prosedur penelitian yang menghasilkan data deskriptif berupa kata-kata tertulis atau lisan dari orang-orang dan perilaku yang diamati. ${ }^{\mathbf{8}}$

Sejalan dengan definisi tersebut, Kirk dan Miller mendefinisikan bahwa penelitian kualitatif adalah tradisi tertentu dalam ilmu pengetahuan sosial yang secara fundamental bergantung dari pengamatan pada manusia baik dalam kawasannya maupun dalam persitilahannya.

Selanjutnya david Wiliams mendefinisikan bahwa penelitian kualitatif ialah pengumpulan semua data pada suatu latar alamiah, dengan menggunakan metode alamiah, dan dilakukan oleh orang atau peneliti yang tertarik secara alamiah.

Lexy J Moleong selanjutnya memberikan ciri-ciri dalam penelitian kualitatif yakni:

a. Latar alamiah. Yakni penelitian dialakukan pada latar alamiah atau pada konteks dari suatu keutuhan.

b. Manusia sebagai alat (instrumen). Yakni peneliti sendiri tau dengan bantuan orang lain merupakan alat pengumpul data utama.

c. Metode kualitatif. Yakni penelitian menggunkan metode kualitatif yaitu, pengamatan wawancara, dan penelaan dokumen.

${ }^{6}$ Nana Syaodih Sukmadinata, Metode Penelitian Pendidikan (Bandung: Remaja Rosdakarya, 2007), h. 18.

${ }^{7}$ Nana Syaodih Sukmadinata, Metode Penelitian Pendidikan, h. 33.

${ }^{8}$ Lexy J. Moleong, Metodologi Penelitian Kualitatif (edisi revisi), (Bandung: PT Remaja Rosadakarya, 2005), h. 4-5 


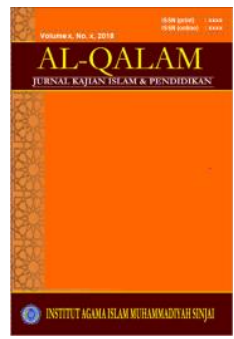

AL-QALAM

Jurnal Kajian Islam \& Pendidikan

Volume 9, No. 1, 2017

ISSN (print) : 1858-4152

ISSN (online) : :xxx-xxxx

Homepage : http://journal.iaimsinjai.ac.id/index.php/al-qalam

d. Analisis data secara induktif

e. Teori dari dasar

f. Deskriptif. Yakni data yang dikumulkan berupa kata-kata, gambar dan bukan angka-angka

g. Lebih mementingkan proses dari pada hasil

h. Adanya batas yang ditentukan oleh fokus

i. Adanya kriteria khusus untuk keabsahan data

j. Desain yang hanya bersifat sementara. Yakni penyusunan desain secara terus menerus diseuaikan dengan kenyataan dilapangan.

k. Hasil penelitian dirundingkan dan disepakati bersama. ${ }^{9}$

\section{B. Data dan Sumber Data Peneltian}

Data penelitian membantu seorang peneliti kualitatif untuk membuat keputusan ataupun menyimpan informasi yang diperolehnya. Hal tersebut dilakuakan dengan jalan mengumpulkan pengetahuan secukupnya yang mengarahkan sesorang pada upaya memahami dan menjelaskannya. data dari penelitian ini adalah mengenai peran guru dan kepala sekolah dalam pengembangan kurikulum pendidikan dasar.

Berdasarkan konsep diatas maka yang menjadi sumber data dalam penelitian ini adalah kepala sekolah, guru dan waka kurikulum di MTs. Muhammadiyah Balangnipa Sinjai Utara, Kecamatan Sinjai Utara

\section{Teknik Pengumpulan Data}

Teknik atau prosedur pengumpulan data merupakan langkah yang paling utama dalam penelitian. Karena tujuan utama dari penelitian adalah mendapatkan data. Tanpa mengetahui dan memilik teknik pengumpulan data, maka peneliti tidak akan mendapatkan data yang memenuhi standar data yang ditetapkan.

${ }^{9}$ Lexy J. Moleong, Metodologi Penelitian Kualitatif(edisi revisi), h. 8 


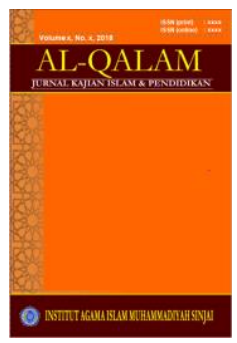

AL-QALAM

Jurnal Kajian Islam \& Pendidikan

Volume 9, No. 1, 2017

ISSN (print) : 1858-4152

ISSN (online) : :xxx-xxxx

Homepage : http://journal.iaimsinjai.ac.id/index.php/al-qalam

Olehnya itu, untuk memperoleh data yang valid dalam kegiatan penelitian ini, maka perlu ditentukan teknik-teknik dalam pengumpulan data yang sesuai dan sistematis. Dalam penelitian ini, peneliti menggunakan teknik-teknik sebagai beriku:

1. Pengamatan dan obeservasi

Obeservasi adalah metode pengamatan baik secara langsung maupun tidak langsung terhap objek penelitian . ada definis lain yaitu pengumpulan data dengan melakukan pengamatan secara sistematis terhadap gejala-gejala nampak pada objek penelitian. ${ }^{10}$

Pelaksanaan observasi dilakukan dengantiga cara:

a. Pengamatan secara langsung yaitu pengamatan yang dilakukan tanpa perantara terhadap objek yang diteliti

b. Pengamatan tidak langsung yaitu pengamatan terhadap suatu objek melalui perantara suatu alat atau cara baik dilakukan dalam situasi sebenarnya atau tiruan.

c. Partisipatif yaitu pengamatan yang dilakukan dengan cara ikut serta dalam kegiatan-kegiatan yang dilakukan oleh objek yang diteliti.

Berdasarkan ketiga cara tersebut, maka dalam penelitian ini peneliti menggunakan pengamatan langsung dan partisipasi. observasi dilakukan untuk mengumpulkan data yang berkaiatan dengan konsep guru tentang peran guru dan kepala sekolah dalam pengembangan kurikulum madrasah.

2. Teknik wawancara dan interview

Wawancara adalah percakapan dengan maksud tertentu. Percakapan itu dilakukan oleh dua pihak, pewawancara yang mengajukan pertanyaan dan yang diwawancarai yang memberikan jawaban pertanyaan itu. ${ }^{\mathbf{1 1}}$

\footnotetext{
${ }^{10}$ Hadari Nawawi, Metode Penelitian Bidang Sosial, (Yogyakarta: Gajah Mada Press. 1993), h. 100

${ }^{11}$ Lexy J. Moleong, Metodologi Penelitian Kualitatif(edisi revisi), h. 186
} 


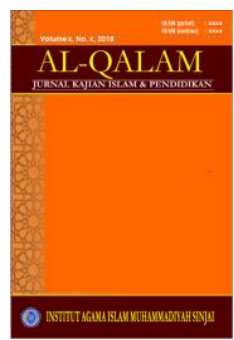

AL-QALAM

Jurmal Kajian Islam \& Pendidikan

Volume 9, No. 1, 2017

ISSN (print) : 1858-4152

ISSN (online) : :xxx-xxxx

Homepage : http://journal.iaimsinjai.ac.id/index.php/al-qalam

Menurut Suharsimi Arikunto, hal-hal yang dibicarakan dalam teknik wawancara adalah sebagai berikut:

a. Menentukan informan yang diwawancarai

b. Persiapan wawancara dan garis besar pertanyaan

c. Menetapkan waktu

d. Selama proses wawancara berlangsung peneliti harus dapat menciptakan suasana santai tapi serius

e. Mengakhiri wawancara dengan segera meyakin dalam transkip nilai wawancara.

Metode ini merupakan pengumpulan data yang utama, yang dipakai untuk mengali data yang tidak mungkin dpat digali dengan metode yang lain, seperti metode observasi dan dokumentasi. Dalam penelitian ini yang akan dijadikan informan atau orang yang diwawancarai adalah seluruh unsur yang ada di sekolah dasar

\section{Dokumentasi}

Tidak kalah penting dari metode-metode yang lain, adalah metode dokumntasi, yaitu mencari data mengenai hal-hal atau variabel yang berupa catatan, transkip, buku, surat kabar, majalah, notulen rapat, agenda dan sebagainnya. ${ }^{12}$

\section{Teknik Analisis Data}

Data yang telah terkumpul harus diolah atau dianalisis terlebih dahulu sebelum mendapatkan sebuah kesimpulan. Analisis data menurut adalah proses mencari dan menyusun secara sistematis data yang diperoleh dari hasil wawancara, catatan lapangan, dan dokumentasi dengan cara mengorganisasikan data ke dalam kategori, menjabarkan ke dalam unit-unit, kemudian melakukan sintasa dan menyusunnya ke dalam pola, memilah mana yang penting dan yang akan dipelajari,

${ }^{12}$ Suharsismi Arikunto, Prosedur Penelitian Suatu Pendekatan Praktik (edisi revisi VI), (Jakarta: Rineka Cipta, 2006), h. 231 


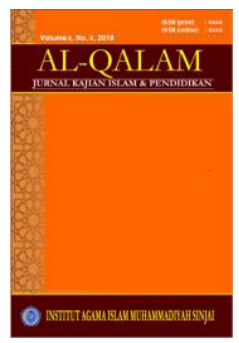

AL-QALAM

Jurnal Kajian Islam \& Pendidikan

Volume 9, No. 1, 2017

ISSN (print) : 1858-4152

ISSN (online) : xxxx-xxxx

Homepage : http://journal.iaimsinjai.ac.id/index.php/al-qalam

dan terakhir adalah membuat kesimpulan yang dapat dipahami. Analisis data dalam penelitian kualitatif bersifat induktif yaitu berdasarkan analisis data yang diperoleh, selanjutnya dikembangkan menjadi hipotesis, dan apabila hipotesis itu diterima, maka hipotesis itu berkembang menjadi teori. ${ }^{13}$

Analisis data dalam penelitian kualitatif dilakukan pada saat pengumulan data berlangsung hingga setelah selesai pengumpulan data dalam periode tertentu. Aktivitas analisis data kualitatif dilakukan secara interaktif dan berlangsung secara terus menerus hingga tuntas hingga datanya jenuh. Data jenuh adalah keadaan di mana data yang telah diperoleh dari berbagai sumber dan teknik hasilnya tetap sama. Analisis data yang digunakan dalam penelitian ini adalah model Miles and huberman. Aktivitas dalam analisis data yaitu reduksi data, penyajian data dan membuat kesimpulan. Berikut akan dipaparkan lebih dalam aktivitas dalam analisis data dalam penelitian ini adalah sebagai berikut: ${ }^{14}$

1. Data Reduction/Reduksi data

Banyaknya jumlah data yang diperoleh dari informan membuat tingkat variasi informasi menjadi lebih kompleks dan rumit sehingga perlu direduksi atau disingkirkan data yang tidak dibutuhkan. Mereduksi data berarti merangkum, memilah-milah hal-hal yang pokok, memfokuskan pada hal-hal yang penting, dicari tema dan polanya. Dengan demikian data yang diperoleh setelah reduksi akan memberikan gambaran yang lebih jelas, dan mempermudah peneliti untuk melakukan pengumpulan data selanjutnya.

Dalam penelitian ini reduksi data dilakukan yaitu dengan cara memilahmilah data yang telah diperoleh dari informan, kemudian mengelompokan data-data yang tidak mendukung atau

tidak sesuai dengan data yang dibutuhkan. Selanjutnya di sederhanakan agar data yang diperoleh ketika penyajian data dapat mudah untuk dipahami.

2. Data Display/Penyajian data

\footnotetext{
${ }^{13}$ Sugiyono, Metode Penelitian Kuantitatif, Kualitatif dan R\&D, (Bandung: Alfabeta, 2010), h. 89

${ }^{14}$ Sugiyono, Metode Penelitian Kuantitatif, Kualitatif dan $R \& D$, h 91
} 


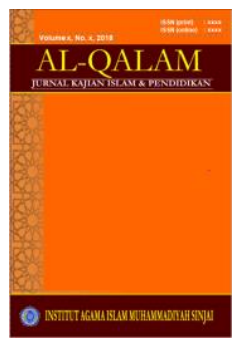

AL-QALAM

Jurnal Kajian Islam \& Pendidikan

Volume 9, No. 1, 2017

ISSN (print) : 1858-4152

ISSN (online) : xxxx-xxxx

Homepage : http://journal.iaimsinjai.ac.id/index.php/al-qalam

Setelah data direduksi atau dipilah-pilah mana yang diperlukan dan mana yang tidak diperlukan, langkah selanjutnya adalah display data atau penyajian data. Melalui penyajian data tersebut, maka data terorganisasikan, tersusun dalam pola hubungan, sehingga akan mudah dipahami. Penyajian data dalam penelitian kualitatif bisa dilakukan dalam bentuk uraian singkat, bagan, hubungan antar kategori. Dengan mendisplay data, akan memudahkan peneliti unutk memahami apa yang terjadi, merencanakan kerja selanjutnya berdasarkan apa yang telah dipahami tersebut. ${ }^{15}$ Dalam penelitian ini penyajian data dilakukan dalam bentuk uraian-uraian singkat agar lebih mudah untuk dideskriptifkan dan ditarik kesimpulan.

3. Conclusing Drawing/verivication/kesimpulan

Langkah terakhir dalam analisis data kualitatif yaitu menarik sebuah kesimpulan dari apa yang telah diteliti. Kesimpulan dalam penelitian kaulitatif merupakan temuan baru yang sebelumnya remang-remang atau gelap sehingga setelah diteliti menjadi jelas, dapat berupa hubungan kausal atau interaktif, hipotesis, atau teori. Dengan demikian kesimpulan dalam penelitian kualitatif mungkin menjawab rumusan masalah yang dirumuskan sejak awal, tetapi mungkin tidak, karena masalah dan rumusan masalah dalam penelitian kualitatif masih bersifat sementara dan akan berkembang setelah peneliti di lapangan. ${ }^{16}$

Dalam penelitian ini kesimpulan diperoleh ketika reduksi data dan penyajian data mengenai peran guru dan kepala sekolah dalam pengembangan kurikulum pendidikan dasar.

\section{PEMBAHASAN}

\section{A. Definisi Kurikulum}

Kurikulum ditinjau dari asal katanya, berasal dari bahasa Yunani yang mulamula digunakan dalam bidang olahraga. Yaitu kata Currete, yang berarti jarak

\footnotetext{
${ }^{15}$ Sugiyono, Metode Penelitian Kuantitatif, Kualitatif dan $R \& D$, h. 93

${ }^{16}$ Sugiyono, Metode Penelitian Kuantitatif, Kualitatif dan R\&D, h. 95
} 


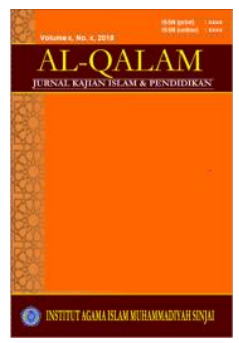

AL-QALAM

Jurnal Kajian Islam \& Pendidikan

Volume 9, No. 1, 2017

ISSN (print) : 1858-4152

ISSN (online) : xxxx-xxxx

Homepage : http://journal.iaimsinjai.ac.id/index.php/al-qalam

tempuh lari, dalam kegiatan berlari, tentu saja ada yang harus ditempuh mulai dari start sampai dengan finis. Jarak dari star sampai dengan finis disebut currere. ${ }^{17}$

Kurikulum adalah seperangkat rencana dan pengaturan mengenai tujuan, isi dan bahan pelajaran serta cara yang digunakan sebagai pedoman penyelenggaraan kegiatan pembelajaran untuk mencapai tujuan pendidikan tertentu. ${ }^{18}$

Menurut Soemarti Patmonodewo, kurikulum adalah suatu perencanaan proses yang akan terjadi seluruhnya di sekolah. Rancangan tersebut merupakan silabus yang berupa daftar judul pelajaran dan urutan alat tersebut secara runtut sehingga merupakan program. ${ }^{19}$

Kurikulum adalah seperangkat rencana dan pengetahuan mengenai tujuan kompetensi dasar, materi standar dan hasil belajar, serta cara yang digunakan sebagai pedoman penyelenggaraan kegiatan pembelajaranuntuk mencapai kompetensi dasar dan tujuan pendidikan. ${ }^{20}$

Kurikulum menurut Suryo Subroto, kurikulum adalahpengalaman pendidikan yang diberikan oleh sekolah kepada seluruh anakdidiknya, baik dilakukan di dalam sekolah maupun di luar sekolah,pengalaman anak didik di sekolah dapat diperoleh melalui beberapakegiatan pendidikan antara lain: mengikuti pelajaran di kelas, praktekketerampilan, latihan olahraga, kesenian dan kegiatan karya wisata ataupraktek dalam laboratorium di sekolah. ${ }^{21}$

Dari beberapa definisi kurikulum yang telah disebutkan di atas bisa diambil kesimpulan bahwa kurikulum merupakan pengalaman peserta didik baik di sekolah maupun di luar sekolah di bawah bimbingan sekolah. Kurikulum tidak hanya terbatas

\footnotetext{
${ }^{17}$ Khaeruddin, Mahfud Junaedi, Kurikulum Tingkat Satuan Pendidikan Konsep dan Implementasi di Masyarakat, Cet Ke 2 (Jogyakarta: Pilar Mandiri, 2007), h.23.

${ }^{18}$ Undang-undang RI No. 20 tahun 2003 Tentang Sistem Pendidikan Nasional.

${ }^{19}$ Soemartin Pramonodawo, Pendidikan Anak Prasekolah, Cet Ke 2(Jakarta: Rineka Cipta, 2003), h. 54 2006), h. 46

${ }^{20}$ Mulyasa, Kurikulum Tingkat Satuan Pendidikan, Cet Pertama (Bandung: Remaja Rosdakarya,

${ }^{21}$ Suryo Subroto, Manajemen Pendidikan Indonesia, (Jakarta: Rineka Cipta, 2004), h. 32
} 


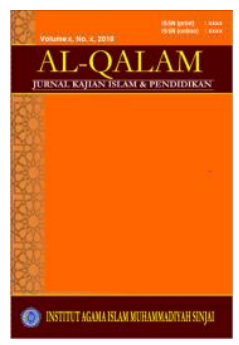

AL-QALAM

Jurnal Kajian Islam \& Pendidikan

Volume 9, No. 1, 2017

ISSN (print) : 1858-4152

ISSN (online) : xxxx-xxxx

Homepage : http://journal.iaimsinjai.ac.id/index.php/al-qalam

pada mata pelajaran tetapi meliputi segala sesuatu yang dapat mempengaruhi perkembangan peserta didik dan bisa menentukan arah atau mengantisipasi sesuatu yang akan terjadi. Dengan kata lain kurikulum haruslah dapat menyajikan apa yang diperlukan peserta didik dengan melihat kebutuhan masyarakat luas.

Kurikulum menjadi bagian yang tidak terlepaskan dalam setiap pembahasan maupun uraian tentang materi dan bahan ajar yang harus diberikan guru kepada siswanya. Semua hal yang berhubungan dengan sasaran keilmuan, teknik pembelajaran maupun standar kompetensi proses belajar mengajar siswa di sekolah dapat diketahui dan diukur keberhasilannya.

\section{B. Pengertian Pengembangan Kurikulum}

Pada dasarnya pengembangan kurikulum adalah mengarahkan kurikulum sekarang ke tujuan pendidikan yang diharapkan karana adanya berbagai pengaruh yang sifatnya positif yang datangnya dari luar atau dari dalam sendiri dengan harapan agar peserta didik dapat menghadapi masa depannya dengan baik. $^{22}$

Definisi lain menjelaskan bahwa pengembangan kurikulum adalah proses perencanaan kurikulum agar menghasilkan rencana kurikulum yang luas dan spesifik. Proses ini berhubungan dengan seleksi dan pengorganisasian berbagai komponen situasi belajar mengajar antara lain penetapan jadwal pengorganisasian kurikulum dan spesifikasi tujuan yang disarankan, mata pelajaran, kegiatan, sumber, dan alat pengukur pengembanagn kurikulum yang mengacu pada kreasi sumber unit, rencana unit, dan garis pelajaran kurikulum lainnya untuk memudahkan proses belajar mengajar. ${ }^{23}$

Berikut ini adalah beberapa karakteristik dalam pengembangan kurikulum:

${ }^{22}$ http://D:/kurikulum/peran-guru-dalam-pengembangan-kurikulum:html. (di akses pada tanggal 15 maret 2015)

${ }^{23}$ Oemar Hamalik, Dasar-Dasar Pengembangan Kurikulum, (Bandung: PT Remaja Rosdakarya, 2007), h. 183-184 


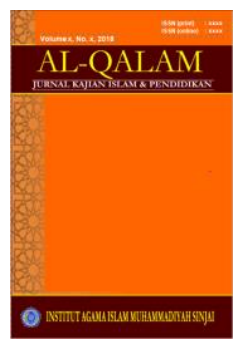

AL-QALAM

Jurnal Kajian Islam \& Pendidikan

Volume 9, No. 1, 2017

ISSN (print) : 1858-4152

ISSN (online) : :xxx-xxxx

Homepage : http://journal.iaimsinjai.ac.id/index.php/al-qalam

1. Rencana kurikulum harus dikembangkan dengan tujuan (goals dan general objectifes) yang jelas.

2. Suatu progam atau kegiatan yang dilaksanakan di sekolah merupakan bagian dari kurikulum yang dirancang selaras dengan prosedur pengembangan kurikulum.

3. Rencana kurikulum yang baik dapat menghasilkan terjadinya proses belajar yang baik karena berdasarkan kebutuhan dan minat siswa.

4. Rencana kurikulum harus mengenalkan dan mendorong difersitas diantara para pelajar.

5. Rencana kurikulum harus menyiapkan semua aspek situasi belajar mengajar, seperti tujuan konten, aktifitas, sumber, alat pengukuran, penjadwalan, dan fasilitas yang menunjang.

6. Rencana kurikulum harus dikembangkan dengan karakteristik siswa pengguna.

7. The subject Arm Approach adalah pendekatan kurikulum yang banyak di gunakan di sekolah.

8. Rencana kurikulum harus memberikan fleksibilitas untuk memungkinkan terjadinya perencanaan guru - siswa .

9. Rencana kurikulum harus memberikan fleksibilitas yang memungkinkan masuknya ide-ide spontan selama terjadinya interaksi antara guru dan siswa dalam situasi belajar yang khusus.

10. Rencana kurikulum sebaiknya merefleksikan keseimbangan antara kognitif, afektif, dan psikomotorik. ${ }^{24}$

Sejalan dengan pengertian pengmbangan kurikulum sebagaimana tersebut diatas, maka proses pengembangannya ada beberapa tahap yaitu sebagai berikut:

1. Visi yang di canangkan

\footnotetext{
${ }^{24}$ Ibid, h. 184-185
} 


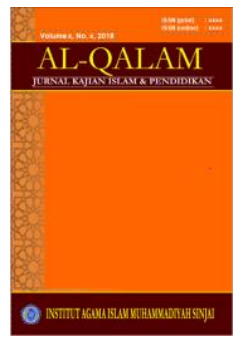

AL-QALAM

Jurnal Kajian Islam \& Pendidikan

Volume 9, No. 1, 2017

ISSN (print) : 1858-4152

ISSN (online) : :xxx-xxxx

Homepage : http://journal.iaimsinjai.ac.id/index.php/al-qalam

Visi adalah pernyataan tentang cita-cita atau harapan-harapan yang ingin dicapai oleh suatu lembaga pendidikan dalam jangka panjang.

2. Kebutuhan stakeholders (siswa, masyarakat, pengguna lulusan), dan kebutuhan untuk studi lanjut.

3. Hasil evaluasi kurikulum sebelumnya dan tuntutan perkembangan iptek dan zaman.

4. Pandangan-pandangan para pakar dengan berbagai latar belakannya.

5. Kecenderungan era globalisasi, yang menuntut seseorang untuk memiliki etos belajar sepanjang hayat, melek sosial, ekonomi, politik, budaya dan teknologi. $^{25}$

Kelima ide tersebut kemudian diramu sedemikian rupa untuk dikembangkan dalam program atau kurikulum sebagai dokumen yang antara lain berisi, informasi dan jenis dokumen yang akan dihasilkan, bentuk format silabus, dan komponenkomponen kurikulum yang harus dikembangkan. Apa yang tertuang dalam dokumen tersebut kemudia dikembangkan dan disosialisasikan dalam proses pelaksanaannya, yang dapat berupa pengembangan kurikulum. ${ }^{26}$

\section{Peran Guru Dalam Pengembangan Kurikulum}

Pendidikan berintikan interaksi antara pendidik (guru) dan peserta didik (siswa) untuk mencapai tujuan-tujuan pendidikan.Pendidik, peserta didik, dan tujuan pendidikan merupakan komponen utama pendidikan.Ketiganya membentuk suatu triangle, jika hilang salah satu komponen, hilang pulalah hakikat pendidikan. Dalam situasi tertentu tugas guru dapat diwakilkan atau dibantu oleh unsur lain seperti oleh media teknologi, tetapi tidak dapat digantikan. Mendidik adalah

${ }^{25}$ Muhaimin, Pengembangan Kurikulum Pendidikan Agama Islam, (Jakarta: PT Rajagrafindo Persada, 2005), h. 13

${ }^{26}$ Ibid, h. 14 


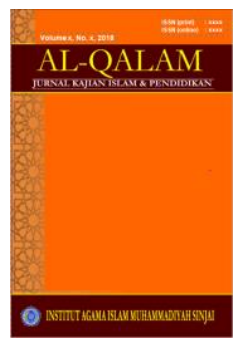

AL-QALAM

Jurnal Kajian Islam \& Pendidikan

Volume 9, No. 1, 2017

ISSN (print) : 1858-4152

ISSN (online) : xxxx-xxxx

Homepage : http://journal.iaimsinjai.ac.id/index.php/al-qalam

pekerjaanprofessional, oleh karena itu guru sebagai pelaku utama pendidikan merupakan pendidik professional. ${ }^{27}$

Departemen pendidikan dan kebudayaan (1980) telah merumuskan kemampuankemampuan yang harus dimiliki guru dan mengelompokkannya atas tiga dimensi umum kemampuan, yaitu; kemampuan professional, kemampuan social, dan kemampuan personal. ${ }^{28}$

Kemampuan profesional disini bukan hanya dalam penguasaan materi pelajaran, akan tetapi juga memiliki dan mengetahui strategi, permainan edukasi, ide atau sesuatu yang dapat menciptakan suasana aktif dalam pembelajaran yang bermakna.Adapun kemampuan sosial adalah; guru dapat berkomunikasi secara efektif baik kepada peserta didik, teman-teman guru, kepala sekolah, orang tua murid ataupun masyarakat sekitar.

Dan yang terakhir adalah kemampuan personal, dimana guru dituntut memiliki sikap dan penampilan yang positif, karena seyogyanya guru adalah model bagi murid-muridnya, maka tidaklah salah jika pepatah mengatakan "guru kencing berdiri, murid kencing berlari".Berbicara tentang pengembangan kurikulum, penulis akan langsung menjelaskan sedikit tentang definisi tersebut yakni, pengembangan kurikulum adalah perencanaan kesempatan-kesempatan belajar yangdimaksudkan untuk membawa siswa ke arah perubahan-perubahan yang diinginkan dan menilai hingga mana perubahan-perubahan itu telah terjadi pada diri siswa. $^{29}$

Jika diteliti lebih jauh, terdapat beberapa kata yang perlu digarisbawahi yakni perencanaan, perubahan, dan menilai yang semua itu berada di bawah tugas seorang guru.Adalah wajar jika guru menempati peran yang cukup penting dalam

${ }^{27}$ Nana Syaodih Sukmadinata, Pengembangan Kurikulum Teori Dan Praktek, (Bandung: Remaja Rosdakarya, 2002), h. 191

${ }^{28}$ Saiful Arif, Pengembangan Kurikulum, (Pamekasan: Stain Pamekasan Press, 2009), h. 130

${ }^{29}$ Oemar Hamalik, Manajemen Pengembangan Kurikulum, (Bandung: Remaja Rosdakarya, 2008), h. 97 


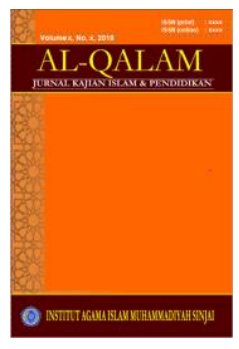

AL-QALAM

Jurnal Kajian Islam \& Pendidikan

Volume 9, No. 1, 2017

ISSN (print) : 1858-4152

ISSN (online) : xxxx-xxxx

Homepage : http://journal.iaimsinjai.ac.id/index.php/al-qalam

pengembangan kurikulum, karena seorang guru, dialah orang yang paling mengerti dan mengetahui situasi dan kondisi hasil belajar peserta didiknya serta bertanggung jawab penuh didalamnya. Kegiatan pembelajaran yang dilakukan oleh guru berpangkal pada suatu kurikulum, dan dalam proses pembelajaran guru juga berorientasi pada tujuan kurikulum. Pada sisi lain, guru adalah pembelajar siswa, yang secara kreatif membelajarkan siswa sesuai dengan kurikulum sekolah. Hal itu menunjukkan bahwa dalam tugas pembelajaran dipersyaratkan agar guru memahami kurikulum. ${ }^{30}$

Banyak dari para guru yang malas diajak berpikir dan berubah secara dinamis.Mereka lebih suka makan matangnya (produknya) daripada berproses, yang membutuhkan kesungguhan intelektual dan komitmen tinggi. Sedangkan proses jauh lebih penting dan menentukan kualitas seseorang dari pada produknya. Proses akan mendinamisasi dan merevitalisasiparadigma berpikir mereka menjadi progresif,proaktif, dan produktif. Kemampuan analisis, menciptakan solusi, dan mengkonsepkan teknis aplikasi mereka akan terasah. ${ }^{31}$

Kata "mereka" pada kalimat diatas mengisyaratkan bahwa sejatinya bukan hanya guru yang perlu dibina, akan tetapi kepala sekolah dan pengawas pendidikan juga perlu dibekali tentang bagaimana mengaplikasikan sebuah kurikulum, guna meninjau kinerja guru serta mengavaluasi mereka. Tidaklah baik kiranya jika seorang guru dapat mengimplementasikan sebuah kurikulum tanpa adanya evaluasi dan dukungan dari pengawas ataupun kepala sekolah. Meski begitu, kita tak bisa memungkiribahwa yang menempati posisi kunci dalam hal ini adalah guru.Seperti yang disebutkan Oemar Hamalik dalam bukunya, "demikian pula guru harus mampu membuat aneka macam keputusan dalam pembinaan kurikulum. Pada dasarnya betapa pun baiknya suatu kurikulum, berhasil atau tidaknya akan sangat

\footnotetext{
${ }^{30}$ Dimayati \& Mudjiono, Belajar Dan Pembelajaran, (Jakarta: Rineka Cipta, 2009), h. 288

${ }^{31}$ Jamal Makmur Asmani, Tips Efektif Aplikasi Ktsp Di Sekolah, (Yogyakarta: Bening, 2010),
} h. 208 


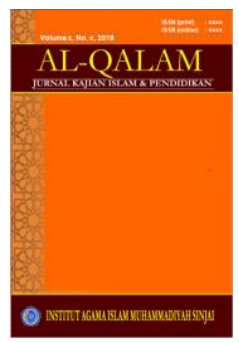

AL-QALAM

Jurnal Kajian Islam \& Pendidikan

Volume 9, No. 1, 2017

ISSN (print) : 1858-4152

ISSN (online) : xxxx-xxxx

Homepage : http://journal.iaimsinjai.ac.id/index.php/al-qalam

bergantung kepada tindakan-tindakan guru di sekolah dalam melaksanakan kurikulum itu. ${ }^{32}$

Beberapa peran guru dalam pengembangan kurikulum, untuk mendukung statement bahwasanya guru merupakan salah satu faktor penting dalam implementasi kurikulum. Menurut Murray Printr, terdapat 4 peranan guru dalam pengembangan kurikulum yakni sebagai berikut:implementers, adapters, developers, dan researchers. ${ }^{33}$

Adapun yang harus dilakukan guru dalam mengembangkan kurikulum tersebut sebagai langkah kemandirian guru ataupun kepala sekolah dalam mengimplementasikan kurikulum guna mencapai prestasi dan kualitas pembelajaran yang tinggi sehingga peserta didik dapat mencapai hasil yang optimal, diantaranya sebagai berikut:

1. Melakukan analisis SWOT yakni strength (kekuatan), weakness (kelemahan), opportunities (peluang), dan traith (tantangan). Setelah menganalisis, guru ataupun kepala sekolah dapat berimprovisasi terhadap kurikulum yang diterapkan, mereka diberi kebebasan dan keleluasaan dalam menjabarkan SKKD dan mengembangkan silabus dan RPP sesuai kebutuhan dan karakteristik sekolah.

2. Memahami karakteristik peserta didik, hal ini harus dilakukan sesuai dengan tingkatan peserta didik. Sedikitnya ada 3 hal yang harus dipahami dalam hal ini, yakni pertumbuhan dan perkembangan kognitif, tingkat kecerdasan, kreativitas, serta kondisi fisik.

3. Membina hasrat belajar, dalam hal ini guru diharuskan menciptakan pembelajaran yang efektif dan menyenangkan, selain itu guru juga harus memanfaatkan fasilitas dan sarana pendidikan yang ada untuk menunjang hal tersebut. Adakalanya membawa peserta didik langsung ke sumber

\footnotetext{
${ }^{32}$ Oemar Hamalik, Pendidikan Guru Berdasarkan Pendekatan Kompetensi, (Jakarta: Bumi Aksara, 2008), h. 20

${ }^{33}$ Wina Sanjaya, Kurikulum Dan Pembelajaran, (Jakarta: Kencana, 2006) , h. 28
} 


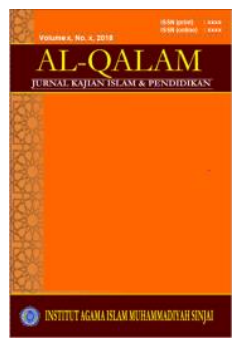

AL-QALAM

Jurnal Kajian Islam \& Pendidikan

Volume 9, No. 1, 2017

ISSN (print) : 1858-4152

ISSN (online) : xxxx-xxxx

Homepage : http://journal.iaimsinjai.ac.id/index.php/al-qalam

berita juga menjadi pilihan yang tepat, dengan tetap mengacu pada anggaran dana yang telah direncanakan.

4. Memantau kemajuan belajar, hal ini berfungsi untuk menciptakan budaya kerja yang efektif dan efisien di kalangan peserta didik maupun di kalangan guru sendiri.

5. Membangun lingkungan yang kondusif, dengan menciptakan dan mendayagunakan fasilitas pendidikan seperti laboratorium, perpustakaan, ruang BK, kantin dll

6. Merevitalisasi forum musyawarah guru, seperti musyawarah guru mata pelajaran (MGMP) yang merupakan suatu wadah yang efektif dalam memantapkan profesi guru, karena didalamnya guru dapat berdiskusi dan menelaah mengenai kesulitannya di kelas serta dapat saling tukar pikiran dalam merancang model pembelajaran dan implementasi kurikulum yang berlaku.

7. Memberdayakan tenaga kependidikan, sebab keberhasilan pendidikan di sekolah sangat ditentukan oleh keterlibatan tenaga kependidikan dalam seluruh kegiatan di sekolah. Dalam hal ini, peningkatan produktifitas dan prestasi kerja dapat dilakukan dengan meningkatkan perilaku tenaga kependidikan di sekolah melalui aplikasi berbagai konsep dan teknik manajemen personalia modern. ${ }^{34}$

Selanjutnya kembali pada peranan guru dalam pengembangan kurikulum, yang pertama adalah sebagai implementers, yakni sebagai pengimplementasi kurikulum.Dalam hal ini, guru hanya mengaplikasikan kurikulum yang telah dibuat oleh pemerintah sebagai tenaga teknis.Dalam hal ini, guru tidak memiliki ruang untuk menentukan isi ataupun target kurikulum.Martinis Yasmin menyebutkan, bahwa guru menerapkan kurikulum yang telah dirancang pemerintah dan institusi,

${ }^{34}$ Mulyasa, Implementasi Kurikulum Tingkat Satuan Pendidikan Kemandirian Guru Dan Kepala Sekolah, (Jakarta: Bumi Aksara, 2009), h. 81 


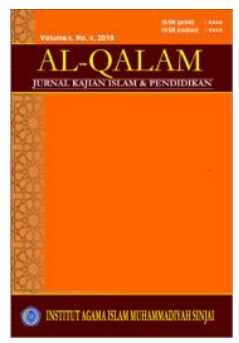

AL-QALAM

Jurnal Kajian Islam \& Pendidikan

Volume 9, No. 1, 2017

ISSN (print) : 1858-4152

ISSN (online) : xxxx-xxxx

Homepage : http://journal.iaimsinjai.ac.id/index.php/al-qalam

dan mereka harus mampu mengajarnya walaupun kurikulum sebelumnya terdapat banyak perubahan.Demikian juga muatan yang terdapat dalam kurikulum. ${ }^{35}$

Kedua, sebagai adapters, yakni peran guru sebagai pelaksana kurikulum.Bukan hanya itu, guru juga diperbolehkan untuk menyelaraskan kurikulum yang ada dengan situasi, kondisi dan kebutuhan siswa dalam suatu daerah.Peran ini lebih luas cakupannya dibanding dengan peran guru sebagai implementers, sebagai contoh; kebijakan dalam kurikulum tingkat satuan pendidikan (KTSP), para perancang kurikulum hanya menentukan standar isi sebagai standar minimal yang harus dicapai.Bagaimana implementasinya, kapan waktunya dan hal-hal teknis lainnya seluruhnya ditentukan oleh guru. Dengan demikian guru akan lebih merasa tertantang untuk memvariasikan kegiatan pembelajaran dan terhindar dari rutinitas yang menjemukan karena memiliki kesempatan dalam mengembangkan kreatifitas yang dimilikinya.

Ketiga, sebagai developers, yakni peran guru sebagai pengembang kurikulum.Dalam hal ini, guru dapat mendesain kurikulum sesuai dengan visi dan misi sekolah.Ini merupakan salah satu dari kelebihan kurikulum KTSP yang sedang berlaku saat ini yakni, memberikan otonomi luas kepada sekolah dan satuan pendidikan.Salah satu contohnya, adalah pengembangan muatan lokal dan pengembangan diri yang berbeda antara satu sekolah dengan sekolah lainnya.

Keempat, sebagai researchers, yakni peran guru sebagai peneliti kurikulum. Guru yang professional akan meneliti dulu kurikulum yang akan digunakan untuk meningkatkan kinerjanya sebagai seorang guru. Dalam buku profesi keguruan disebutkan, di dalam pelaksanaan kurikulum tugas guru adalah mengkaji kurikulum tersebut melalui kegiatan perseorangan atau kelompok (dapat dengan sesama guru di satu sekolah, dengan guru di sekolah lain atau dengan kepala sekolah dan

${ }^{35}$ Martinis Yasmin, Profesionalisasi Guru Dan Implementasi Ktsp, (Jakarta: Gaung Persada, 2008), h. 49 


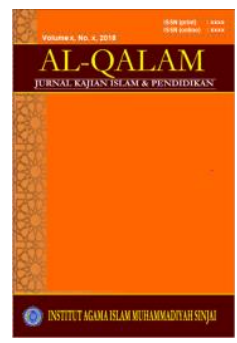

AL-QALAM

Jurnal Kajian Islam \& Pendidikan

Volume 9, No. 1, 2017

ISSN (print) : 1858-4152

ISSN (online) : xxxx-xxxx

Homepage : http://journal.iaimsinjai.ac.id/index.php/al-qalam

personel pendidikan lain seperti pengawas). Dengan demikian guru dan kepala sekolah memahami kurikulum tersebut sebelum dilaksanakan. ${ }^{36}$

\section{Peran Kepala Sekolah Dalam Pengembangan Kurikulum}

Kepala sekolah merupakan tokoh kuci dalam manajemen sekolah. Kepadanyalah kebijakan dan keputusan mengenai berbagai hal.Peran dapat diartikan sebagai perilaku yang diatur dan diharapkandari seseorang dalam posisi tertentu. Pemimpi di dalam organisasimempunyai peranan, setiap pekerjaan membawa serta harapan bagaimanapenanggung peran berperilaku. ${ }^{37}$

Kepala sekolah dalam suatu pendidikan merupakan pemimpin. Ia mempunyai dua jabatan dan peran penting dalam melaksanakan proses pendidikan. Pertama, kepala sekolah adalah pengelola pendidikan di sekolah, dan kedua, kepala sekolah adalah pemimpin formal pendidikan di sekolahnya yang bertanggung jawab mengelola sekolah.Sebagai pengelola pendidikan, kepala sekolah bertanggung jawab terhadap keberhasilan penyelenggaraan kegiatan pendidikan dengan cara melaksanakan administrasi sekolah dengan seluruh substansinya. Di samping itu, kepala sekolah bertanggung jawab terhadap kualitas sumberdaya manusia yang ada agar mereka mampu menjalankan tugastugas pendidikan. Oleh karenanya kepala sekolah pun melaksanakan tugasnya untuk mengembangkan kinerja para personil (terutama para guru) ke arah profesionalisme yang diharapkan. ${ }^{38}$

Dalam pelaksanaannya, pekerjaan kepala sekolah merupakan pekerjaan berat yang menuntut kemampuan ekstra. Meskipun pengangkatan kepala sekolah tidak dilakukan secara sembarangan, bahkan diangkat dari guru yang sudah berpengalaman atau mungkin sudah lama menjabat sebagai wakil kepala sekolah,

\footnotetext{
${ }^{36}$ Soetjipto \& Rafflis Kosasi, Profesi Keguruan, (Jakarta: Rineka Cipta, 2009), h. 149

${ }^{37}$ Viethza Rivai, Kepemimpinan dan Perilaku Organisasi, (Jakarta: Grafindo Persada, 2003), h. 148

${ }^{38}$ Ara Hidayat, Imam Machali, Pengelolaan Pendidikan Konsep Prinsip dan Aplikasinya dalam Mengelola Sekolah dan Madrasah, (Bandung: Pustaka Edukasi, 2010), h. 144
} 


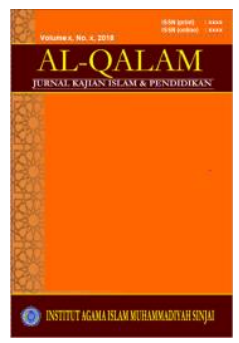

AL-QALAM

Jurnal Kajian Islam \& Pendidikan

Volume 9, No. 1, 2017

ISSN (print) : 1858-4152

ISSN (online) : xxxx-xxxx

Homepage : http://journal.iaimsinjai.ac.id/index.php/al-qalam

namun tidak dengan sendirinya membuat kepala sekolah menjadi profesional dalam melakukan tugasnya.Dinas Pendidikan (dulu: Depdikbud) telah menetapkan bahwa kepala sekolah harus mampu melaksanakan pekerjaannya sebagai edukator; manajer; administrator dan supervisor (EMAS). Dalam perkembangan selanjutnya, sesuai dengan kebutuhan masyarakat dan perkembangan zaman, kepala sekolah pun harus mampu berperan sebagai leader, inovator, dan motivator di sekolahnya. ${ }^{39}$

1. Kepala sekolah sebagai Edukator

Keputusan Menteri pendidikan dan kebudayaan No. 0296/U/1996, merupakan landasan pendidikan kinerja kepala sekolah. Kepala sekolah sebagai edukator harus memiliki kemampuan untuk membimbing guru, membimbing tenaga kependidikan non guru, membimbing peserta didik mengembangkan tenaga kependidikan, mengikuti perkembangan iptek dan memberi contoh mengajar. ${ }^{40}$

Dalam melakukan fungsinya sebagai edukator kepala sekolah harus memiliki strategi yang tepat untuk meningkatkan profesionalisme tenaga kependidikan di sekolah, menciptakan iklim sekolah yang kondusif, memberikan nasehat kepada warga sekolah, memberikan dorongan kepada seluruh tenaga kependidikan, serta melaksanakan model pembelajaran yang menarik, seperti team teaching, moving class, dan mengadakan program akselerasi (acceleration) hingga peserta didik yang cerdas di atas normal. Kepala sekolah sebagai educator harus mampu memberikancontoh kepada para guru, tentang bagaimana menjadi pendidik yangbaik. Oleh karenanya kepala sekolah tidak hanya bekerja sebagaipemimpin para peserta didik, guru, maupun karyawannya akan tetapikepala sekolah juga harus terjun di bidang atau ikut serta dalam prosesbelajar mengajar. Supaya kepala sekolah juga tidak hanya memberikannasehat saja, kepada bawahannya akan tetapi ia juga harus mengetahuibagaimana sebenarnya proses belajar mengajar yang terjadi di sekolah,karena jika tidak demikian bagaimana kepala sekolah

\footnotetext{
${ }^{39}$ Mulyasa, Manajemen Kepala Sekolah Profesional, Cet ke 8 (Bandung: Remaja Rosdakarya, 2007), h. 97-98

${ }^{40}$ Ibid, h. 101
} 


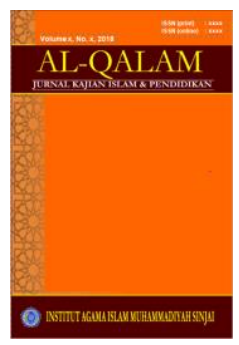

AL-QALAM

Jurnal Kajian Islam \& Pendidikan

Volume 9, No. 1, 2017

ISSN (print) : 1858-4152

ISSN (online) : xxxx-xxxx

Homepage : http://journal.iaimsinjai.ac.id/index.php/al-qalam

akanmeningkatkan mutu dari pendidikan jika kepal sekolah sendiri tidakmengetahui yang sebenarnya apa yang menjadi faktor hambatan dalampengembangan kurikulum dan faktor pendukung dalam pengembangankurikulum. Sehingga kepala sekolah juga mampu mengambil strategiyang akan di gunakan dalam pengembangan kurikulum yang didigunakan di sekolahnya. $^{41}$

\section{Kepala Sekolah sebagai Administrator}

Kepala sekolah sebagai administrator memiliki hubungan yang sangat erat dengan berbagai aktifitas pengelolaan administrasi yangbersifat pencatatan penyusunan dan pendokumentasian seluruhprogram sekolah. Secara spesifik kepala sekolah harus memilikikemampuan untuk mengelola kurikulum, mengelola administrasi peserta didik, mengelola administrasi personal mengelola administrasisarana prasarana dan mengelola administrasi kearsipan dan mengelolaadministrasi keuangan kegiatan tersebut perlu dilakukan secara efektifdan efisien agar dapat menunjang produktivitas sekolah. Untuk itukepala sekolah harus mampu menjabarkan kemampuan tersebut dalamtugas operasional. ${ }^{42}$

Kepala sekolah memiliki tugas yang lebih berkenaan denganimplementasi kurikulum di sekolah. Peran kepala sekolah dan gurusangat besar dan merupakan kunci keberhasilan pengembangankurikulum. ${ }^{43}$

3. Kepala Sekolah sebagai Supervaisor

Kegiatan utama pendidikan sekolah dalam rangka mewujudkan tujuan adalah kegiatan pembelajaran, sebagai seluruh aktifitas organisasi sekolah bermuara pada pencapaian efisiensi dan efektifitas pembelajaran. Oleh karena itu salah satu tugas kepala sekolah adalah sebagai supervisor, yaitu mengawasi pekerjaan yang dilakukan oleh tenaga kependidikan. Sergiovani dan Starat (1993)

${ }^{41}$ Ibid, h. 103-104

${ }^{42}$ Ibid, h. 107

${ }^{43}$ Omar Hamalik, Pendidikan Guru Berdasarkan Pendekatan Kompetensi, (Jakarta: Bumi Aksara, 2008), h. 230 


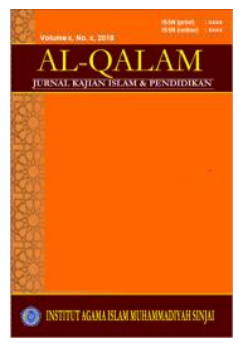

AL-QALAM

Jurnal Kajian Islam \& Pendidikan

Volume 9, No. 1, 2017

ISSN (print) : 1858-4152

ISSN (online) : xxxx-xxxx

Homepage : http://journal.iaimsinjai.ac.id/index.php/al-qalam

menyatakan bahwa "supervision is a process designed to help teacher and supervisorlearn more about their practice; servant parents and to make the school a more effective learning community. ${ }^{44}$

Kutipan tersebut menunjukkan bahwa supervisi merupakan suatu proses yang dirancang secara khusus untuk membantu para guru dan supervisor dalam mempelajari tugas sehari-hari di sekolah agar dapat menggunakan pengetahuan dan kemampuan untuk memberikan layanan yang lebih baik kepada orang tua peserta didik dan sekolahserta berupaya menjadikan sekolah sebagai masyarakat belajar yanglebih efektif. Jika supervisi dilaksanakan kepala sekolah maka ia harus mampu melakukan berbagai pengawasan dan pengendalian untuk meningkatkan kinerja tenaga kependidikan. Pengawasan dan pengendalian ini merupakan kontrol agar kegiatan pendidikan di sekolah terarah pada tujuan yang telah ditetapkan. Pengawasan danpengendalian juga merupakan tindakan preventif untuk mencegah agar para tenaga kependidikan tidak melakukan penyimpangan dan lebih berhatihati dalam melaksanakan pekerjaannya. ${ }^{45}$

Kepala sekolah sebagai supervisor artinya kepala sekolah berfungsi sebagai pengawas, pengendali, pembina, pengarah, dan pemberi contoh kepada para guru dan karyawannya di sekolah. Salah satu hal terpenting bagi kepala sekolah, sebagai supervisor adalahmemahami tugas dan kedudukan karyawan-karyawan atau staf di sekolah yang dipimpinnya. Dengan demikian, kepala sekolah tidak hanya mengawasi karyawan dan guru yang sedang melaksanakan kegiatan, tetapi ia membekali diri dengan pengetahuan dan pemahamannya tentang tugas dan fungsi stafnya, agar pengawasan dan pembinaan berjalan dengan baik dan tidak membingungkan. ${ }^{46}$

\footnotetext{
${ }^{44}$ E Mulyasa, Manajemen Kepala Sekolah Profesional, Cet ke 8 (Bandung: Remaja Rosdakarya, 2007), h. 101

${ }^{45}$ Ibid, h. 111

${ }^{46}$ Harabudin, Administrasi dan Supervisi Pendidikan, (Bandung: Pustaka Setia, 2009), h. 210.
} 


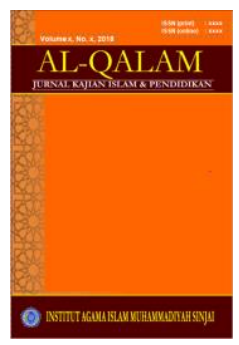

AL-QALAM

Jurnal Kajian Islam \& Pendidikan

Volume 9, No. 1, 2017

ISSN (print) : 1858-4152

ISSN (online) : xxxx-xxxx

Homepage : http://journal.iaimsinjai.ac.id/index.php/al-qalam

Lancar tidaknya suatu sekolah dan mutu tidaknya suatu sekolah tidak hanya tergantung dari jumlah atau kecakapan guru-guru pengajarnya, akan tetapi kelancaran suatu sekolah dan sekolah itu bisa dikatakan bermutu jika pemimpin suatu sekolah dapat melaksanakan kepemimpinannya dan tugas-tugasnya sebagai kepala sekolah dapat berjalan sebagaimana mestinya. ${ }^{47}$ Artinya kepala sekolah harus

menguasai segala peranannya sebagai kepala sekolah meski tidaksemua pekerjaan kepala sekolah dilakukannya sendiri. Tentunya adastaf-staf pembantu pelaksana peranan kepala sekolah. Dengan adanyahal itu tentunya kepala sekolah harus mampu memberikan contoh kepada bawahannya dalam melaksanakan tugas, dan kepala sekolahjuga harus mampu membina dan mengarahkan kepada bawahannyaagar para staf melaksanakan tugasnya secara baik sesuai dengan perencanaan yang telah di tetapkan.

\section{Kepala Sekolah sebagai Manajer}

Manajemen pada hakikatnya merupakan suatu proses merencanakan, mengorganisasikan, melaksanakan, memimpin dan mengendalikan usaha para anggota organisasi serta mendayagunakan seluruh sumber daya organisasi dalam rangka mencapai tujuan yang telah ditetapkan. Dalam rangka melakukan peran dan fungsinya sebagai manajer kepala sekolah harus memiliki strategi yang tepat untuk memberdayakan tenaga kependidikan melalui kerjasama atau kooperatif, memberi kesempatan kepada para tenaga kependidikan untuk meningkatkan profesinya dan mendorong keterlibatan seluruh tenaga kependidikan dalam berbagai kegiatan yang menunjang program sekolah. ${ }^{48}$

\section{Kepala Sekolah sebagai Leader}

Kepala sekolah harus mampu memberikan petunjuk dan pengawasan, meningkatkan kemampuan tentang kependidikan, membuka komunikasi dua arah

\footnotetext{
${ }^{47}$ Daryanto, Administrasi Pendidikan, (Jakarta: Renika Cipta, 2008), h. 182.

${ }^{48}$ Mulyasa, Manajemen Kepala Sekolah Profesional, Cet ke 8 (Bandung: Remaja Rosdakarya, 2007), h.103.
} 


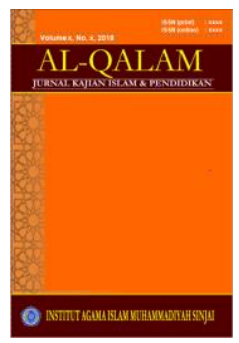

AL-QALAM

Jurnal Kajian Islam \& Pendidikan

Volume 9, No. 1, 2017

ISSN (print) : 1858-4152

ISSN (online) : xxxx-xxxx

Homepage : http://journal.iaimsinjai.ac.id/index.php/al-qalam

dan mendelegasikan tugas. Wahjo Sumijo (1999:1109) mengemukakan bahwa kepala sekolah sebagai leader harus memiliki karakter khusus yang mencakup kepribadian. Keahlian dasar, pengalaman dan pengetahuan profesional serta pengetahuan administrasi dan pengawasan. Kemampuan yang harus diwujudkan kepala sekolah sebagai leader dapat dianalisa dari kepribadian. Pengetahuan terhadap tenaga kependidikan, visi dan misi sekolah, kemampuan mengambil keputusan dan kemampuan berkomunikasi. Kemampuan kepala sekolah sebagai leader akan tercermin dalam sifat jujur, percaya diri, tanggung jawab, berani mengambil resiko dan keputusan, berjiwa besar, emosi yang stabil dan teladan. ${ }^{49}$

6. Kepala sekolah sebagai Innovator

Dalam melakukan peran dan tugasnya sebagai inovator, kepalasekolah harus memiliki strategi yang tepat untuk menjalin hubunganyang harmonis dengan lingkungan, mencari gagasan baru,mengintegrasikan setiap kegiatan, memberikan teladan kepada seluruhtenaga kependidikan di sekolah dan mengembangkan modelmodelpembelajaran inovatif.Kepala sekolah sebagai inovator akan tercermin dari cara-caraia melakukan pekerjaannya secara konstruktif, delegatif, integratifserta adaptatif dan fleksibel. Sebagai innovator harus mampu mencari,menemukan dan melaksanakan berbagai pembaharuan di sekolah.Gagasan baru tersebut misalnya moving class, adalah mengubahstrategi pembelajaran dari pola kelas tetap menjadi kelas bidang studi,sehingga setiap bidang studi memiliki kelas tersebut yang dilengkapidengan alat peraga dan alat-alat lainnya. ${ }^{50}$

7. Kepala Sekolah sebagai Motivator

Sebagai motivator kepala sekolah harus memiliki strategi yang tepat untuk memberikan motivasi kepada para tenaga pendidik dalammelakukan berbagai tugas dan fungsinya. Motivasi ini dapat ditumbuhkan melalui pengaturan lingkungan fisik, pengaturan suasanakerja disiplin, dorongan penghargaan secara efektif dan

\footnotetext{
${ }^{49}$ Ibid, h. 115.
}

${ }^{50}$ Ibid, h. 118-119. 


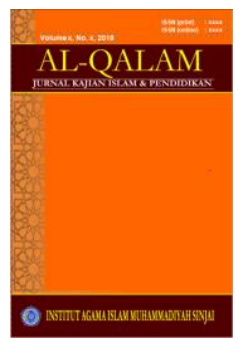

AL-QALAM

Jurnal Kajian Islam \& Pendidikan

Volume 9, No. 1, 2017

ISSN (print) : 1858-4152

ISSN (online) : :xxx-xxxx

Homepage : http://journal.iaimsinjai.ac.id/index.php/al-qalam

penyediaanberbagai sumber belajar melalui pengembangan pusat sumber belajar(PSB). ${ }^{51}$

Setiap tenaga kependidikan memiliki karakteristik khusus, yangberbeda satu sama lain, sehingga memerlukan perhatian dan pelayanankhusus pula dari pemimpinnya, agar mereka dapat memanfaatkanwaktu untuk meningkatkan profesionalismenya, oleh karena itu untukmeningkatkan profesionalisme tenaga kependidikan kepala sekolahharus memperhatikan motivasi para tenaga kependidikan dan faktor-faktorlain yang berpengaruh.

\section{KESIMPULAN}

Berdasarkan pembahasan di atas, dapat disimpulkan bahwa:

1. Kurikulum merupakan bagian dari suatu sistem pengelolaan yang menyangkut perencanaan dan pelaksanaan pembelajaran yang dijadikan pedoman atau panduan bagi guru dalam melaksanakan kegiatan pembelajaran.

Pengembangan kurikulum adalah mengarahkan kurikulum sekarang ke tujuan pendidikan yang diharapkan karana adanya berbagai pengaruh yang sifatnya positif yang datangnya dari luar atau dari dalam sendiri dengan harapan agar peserta didik dapat menghadapi masa depannya dengan baik. Pengembangan kurikulum harus mengacu pada sebuah kerangka umum, yang berisikan hal - hal yang diperlukan dalam pembuatan keputusan yang meliputi asumsi, tujuan pengembangan kurikulum, penilaian kebutuhan, konten kurikulum, sumber materi kurikulum, implementasi kurikulum, evaluasi kurikulum dan keadaan di masa mendatang.

Sumber Daya Manusia (SDM) pengembangan kurikulum adalah kemampuan terpadu dari daya piker dan daya fisik yang dimiliki oleh setiap pengembang kurikulum dari tingkat pusat sampai tingkat daerah. Sumber

${ }^{51}$ Ibid, h. 120. 


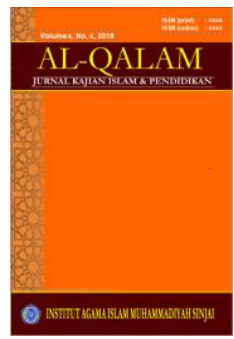

AL-QALAM

Jurnal Kajian Islam \& Pendidikan

Volume 9, No. 1, 2017

ISSN (print) : 1858-4152

ISSN (online) : xxxx-xxxx

Homepage : http://journal.iaimsinjai.ac.id/index.php/al-qalam

daya manusia tersebut terdiri atas berbagai pakar ilmu pendidikan, administrator pendidikan, guru, ilmuwan, orang tua, siswa, dan tokoh masyarakat. Guru merupakan salah satu faktor penting dalam implementasi kurikulum. Bagaimanapun idealnya suatu kurikulum tanpa ditunjang oleh kemampuan guru untuk mengimplementasikannya, maka kurikulum itu tidak akan bermakna sebagai suatu alat pendidikan, dan sebaliknya pembelajaran tanpa kurikulum sebagai pedoman tidak akan efektif. Dari uraian makalah di atas, telah memberikan gambaran kepada kita bahwa guru memegang peranan yang penting dalam pengembangan kurikulum.

2. Peran Guru dan Kepala Sekolah dalam Pengembangan Kurikulum adalah :

Sebagai implementer, guru berperan untuk mengaplikasikan kurikulum yang sudah ada dan kepala sekolah sebagai pengontrol. Dalam pengembangan kurikulum guru dianggap sebagai tenaga teknis yang hanya bertanggung jawab dalam mengimplementasikan berbagai ketentuan yang ada.Sebagai penyelaras kurikulum dengan karakteristik dan dan kebutuhan siswa serta kebutuhan daerah. Guru diberikan kewenangan untuk menyesuaikan kurikuum dengan kebutuhan daerah ataupun karakteristik sekolah. Sebagai pengembang kurikulum, guru memiliki kewenangan dalam mendesain sebuah kurikulum. Guru tidak hanya bisa menentukan tujuan dan isi pelajaran yang akan disampaikan, tetapi bahkan dapat menentukan strategi apa yang harus dikembangkan dan system evaluasi apa yang akan digunakannya. Sebagai pengembang kurikulum guru dan kepala sekolah sepenuhnya dapat menyusun kurikulum sesuai dengan karakteristik, misi dan visi sekolah/madrasah, serta sesuai dengan pengalaman belajar yang diperlukan anak didik. Sebagai peneliti kurikulum (curriculum researcher). Peran ini dilaksanakan sebagai bagian dari tugas professional guru yang memiliki tanggung jawab dalam meningkatkan kinerjanya sebagai guru. Dalam peran ini guru memiliki tanggung jawab untuk menguji berbagai komponen kurikulum, misalnya menguji bahan-bahan kurikulum, menguji 


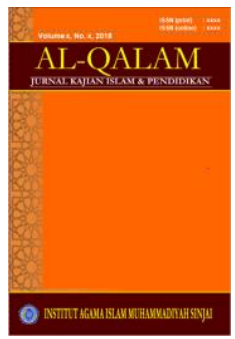

AL-QALAM

Jurnal Kajian Islam \& Pendidikan

Volume 9, No. 1, 2017

ISSN (print) : 1858-4152

ISSN (online) : xxxx-xxxx

Homepage : http://journal.iaimsinjai.ac.id/index.php/al-qalam

efektivitas program, strategi maupun model pembelajaran, termasuk mengumpulkan data tentang keberhasilan siswa mencapai target kurikulum.

\section{DAFTAR PUSTAKA}

Ara Hidayat, Imam Machali,Pengelolaan Pendidikan Konsep Prinsip dan Aplikasinya dalam Mengelola Sekolah dan Madrasah, Bandung: Pustaka Edukasi ,2010.

Damayanti, Mudjiono, Belajar dan Pembelajaran, Jakarta: Reineka Cipta, 2009.

Daryanto, Administrasi Pendidikan, Jakarta: Rineka Cipta , 2008

Hadari Nawawi, Metode Penelitian Bidang Sosial, Yogyakarta: Gajah Mada Press. 1993.

Harabuddin,Administrasi dan Supervisi Pendidikan, Bandung: Pustaka Setia , 2009.

Hamidi, Metode Penelitian Kualitatif (Aplikasi, Paraktis Pembuatan Proposal dan Laporan Penelitian), Malang: UMM Press, 2005.

http://D//kurikulum/peran-guru-dalam-pengembangan-kurikulum:html (di akses pada tanggal 15 maret 2015

Jamal Makmur Asmani, Tips Efektif Aplikasi Ktsp di Sekolah, Yogyakarta: Bening, 2010.

Khairuddin, Mahfud Junaedi, Kurikulum Tingkat Satuan Pendidikan Konsep Dan Implimentasi di Masyarakat Cet ke 2, Yogyakarta: Pilar Mandiri, 2007.

Lexy J. Moleong, Metode Penelitian Kualitatif, Bandung: Remaja Rosdakarya, 2007.

Martinis Yasmin, Profesionalisasi Guru \& Implementasi Ktsp, Jakarta: Gunung Persada, 2008.

Muhaimin, Pengembangan Kurikulum Pendidikan Islam, Jakarta: PT Raja Raja Grafindo Persada, 2005

Mulyasa, Implementasi Kurikulum Tingkat Satuan Pendidikan kemandirian Guru dan Kepala Sekolah, Jakarta: Bumi Aksara, 2009. 


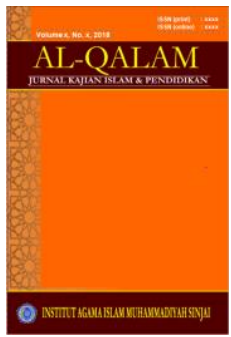

AL-QALAM

Jurmal Kajian Islam \& Pendidikan

Volume 9, No. 1, 2017

ISSN (print) : 1858-4152

ISSN (online) : :xxx-xxxx

Homepage : http://journal.iaimsinjai.ac.id/index.php/al-qalam

Kurikulum Tingkat Satuan Pendidikan Cet pertama, Bandung: Remaja Rosdakarya, 2006

Manajemen Kepala Sekolah Profesional Cet ke 8, Bandung: Remaja Rosda Karya, 2007

Nana Syaodih Sukma Dinata, Pengembangan Kurikulum Teori \& Praktek, Bandung: Remaja Rosdakarya, 2002

Oemar Hamalik, Dasar-Dasar Pengembangan Kurikulum, Bandung: PT Remaja Rosdakarya, 2007

Manajemen Pengembangan Kurikulum, Bandung: PT Remaja Rosdakarya, 2008

Pendidikan Guru Berdasarkan Pendekatan Kompetensi , Jakarta: PT Bumi Aksara, 2008

Saiful Arif, Pengembangan Kurikulum, Pemekasan: STAIN Pemekasan Press, 2009

Soejipto dkk,Profesi Keguruan, Jakarta: Reineka Cipta, 2009.

Soejono dan H. Abdurrahman, Metode Penelitian:Suatu Pemikiran dan Penerapan, Jakarta: PT Rineka Cipta, 1999.

Soemartin Promono Dawo,Pendidikan Anak Prasekolah Cet ke 2, Jakarta: Reineka Cipta, 2003.

Sugiyono,Metode Penelitian Pendidikan, Pendekatan Kuantitatif, dan R\&D(Cet, XI; Bandung: Alfabeta, 2010

Suharsismi Arikunto, Prosedur Penelitian Suatu Pendekatan Praktik (edisi revisi VI), Jakarta: Rineka Cipta, 2006

Suryo Subroto, Manajemen Pendidikan Indonesia, Jakarta: Reineka Cipta, 2004

UU RI No. 20 Tahun 2003 Tentang Satuan Pendidikan Nasional

Vietza Rifai, Kepemimpinan dan Prilaku Organisasi, Jakarta: PT Raja Grafindo Persada, 2003 
Jurnal Kajian Islam \& Pendidikan

Volume 9, No. 1, 2017

ISSN (print) : 1858-4152

ISSN (online) : $\mathrm{xxxx}-\mathrm{xxxx}$

Homepage : http://journal.iaimsinjai.ac.id/index.php/al-qalam 